\title{
Ergonomics in the Contemporary Balinese Building: the Integration between Architectural and Structural Aspects
}

\author{
I Nyoman Sutarja ${ }^{1, *}$ I Dewa Gede Agung Diasana Putra ${ }^{2}$ \\ ${ }^{1}$ Study Program of Civil Engineering, Faculty of Engineering, Udayana University, Badung, 80361, Bali, Indonesia \\ ${ }^{2}$ Study Program of Architecture, Faculty of Engineering, Udayana University, Badung, 80361, Bali, Indonesia
}

Received September 28, 2021; Revised January 4, 2022; Accepted January 16, 2022

\section{Cite This Paper in the following Citation Styles}

(a): [1] I Nyoman Sutarja, I Dewa Gede Agung Diasana Putra, "Ergonomics in the Contemporary Balinese Building: the Integration between Architectural and Structural Aspects, "Civil Engineering and Architecture, Vol. 10, No. 2, pp. 501-512, 2022. DOI: 10.13189/cea.2022.100210.

(b): I Nyoman Sutarja, I Dewa Gede Agung Diasana Putra (2022). Ergonomics in the Contemporary Balinese Building: the Integration between Architectural and Structural Aspects. Civil Engineering and Architecture, 10(1), 501-512. DOI: 10.13189/cea.2022.100210.

Copyright $\bigcirc 2022$ by authors, all rights reserved. Authors agree that this article remains permanently open access under the terms of the Creative Commons Attribution License 4.0 International License

\begin{abstract}
Ergonomic requirements in a building must be reliable. They must meet the safety, health, comfort and convenience requirements specified in the building rules, including the ergonomic safety requirements in a traditional Balinese building. Traditionally, the Balinese utilized their body size to gauge their building's size. However, changes in technology and people's lifestyles have already influenced building techniques. To what extent are ergonomic aspects still used in novel Balinese architecture and building structures? This article examined recent buildings in Bali, integrating architecture, construction, advanced technology and traditional building components. This article analyzed the proper building design and structural system that addresses the ergonomics of the house, the indigenous knowledge of the people, and the advancement of technologies through fieldwork, literature study, interviews and structural analysis using SAP 2000. This study discovered that, traditionally, Balinese people utilized their bodies to determine the scale of their buildings, both in terms of space and structural components. As living standards and technology improved, they have begun to forsake the usage of body parts in measuring buildings. Nowadays, buildings have been designed using meter basis measurement, removing the ability to identify the building's owner using the owner's body as the basic standard for measurement. They also abandoned conventional structural techniques in favor of reinforced concrete systems, especially for non-religious
\end{abstract}

buildings, because reinforced concrete frame structures supported by brick walls are more secure than wooden frame structures. However, the integration during the planning process between architecture and structural design process has still been performed.

Keywords Ergonomic, Anthropometry, Building Structure, Balinese Architecture, Structural Analysis

\section{Introduction}

The requirements of an ergonomic in a building must meet reliability, including safety, health, comfort, and convenience, as a regulation in the law on buildings [1], including the ergonomic requirements of safety in a building related to building structure safety [2] and the occupants' satisfaction [3]. The term ergonomics was coined in 1949, but activities related to it had emerged decades before. The ergonomic considerations were also part of the transformation of human culture 4000 years ago when humans built simple objects like stones to aid hands in accomplishing their jobs [4], including the ergonomic factors in the traditional Balinese building practices. This article investigates the rule of traditional components to handle the ergonomic requirement and the new demand in transforming the building style and system in Bali to 
determine the usage of ergonomic elements in traditional Balinese buildings and their change.

Ergonomics is a science and study of fitting tools, workstations, and jobs to users. It is a goal to avoid bad postures that might cause musculoskeletal problems by reducing ailments, often resulting from tool use or a poor work environment [5]. There has been a substantial amount of academic research on ergonomics, which shows how to design in a way that is advantageous to humans [6]. Ergonomics has become part of science, art, and technology to balance or harmonize all facilities used during physical and mental activities to improve the overall quality of life [7], [8]. Multidisciplinary ergonomic disciplines are well suited for application to all activities in the activities' environment, including in every stage of product development and production, and incorporated into every product development and production stage. Similarly, to how efficient product functions, the ergonomic technique seeks to increase physical comfort, human productivity, safety and improve worker well-being on all levels [9]. Therefore, the safety aspects become important to fulfill ergonomic rules in a building.

In order to address this safety aspect, the integration of architectural and structural design components becomes extremely necessary. Designers must organize the available facilities by analyzing the viability of numerous functional alternatives and architectural forms to meet the ergonomic requirements. In this context, the architectural aspect, which must be functional and aesthetically beautiful, is closely related to the structural analysis process [2]. When selecting a structural system for use in an architectural design process, it is vital to examine its ability to accommodate various functional approaches. The integration process must be completed to accommodate the spatial interweaving of multiple functions, span, height, load, dynamic impact, opening size, and other structural system parameters. These factors are interrelated somehow, and satisfying each component is concurrently [2]. Various function spaces such as swimming pools, meeting rooms, parking lots, and public areas require a unique design grid, and imposing different standards is an essential consideration in a building design process. Each circumstance has its own set of architectural functions and requirements. Differences in operation and requirements are inextricably linked to the building's structural system, which serves as the foundation for all other investment considerations, whether economy or ergonomics.

The integration between architecture and the structural system has already been applied by the Balinese people for their buildings. A Balinese building has been constructed by the layout and spatial arrangement of socio-cultural activities, which is based on the asta kosala kosali principle of design. Among the notions employed in designing a building production according to the anatomy of its owner's human body (anthropometry), this measuring model is tied to the element of ergonomic requirements [10]. However, the advance of technology and the new standard of life requirements have driven the transformation of the Balinese buildings that have changed the nature of the Balinese building practices [11], [12].

This transformation has raised the issue of reconfiguring the architectural pattern and structure, raising questions about the ergonomic matters in recent building productions. Do building productions that have recently been built in Bali still have a traditional ergonomic aspect? Current technology, requirements, and standards about the human life cycle, including virus outbreaks, present a challenge for planners, architects, and structural engineers to produce a building that meets ergonomic requirements, occupants' basic needs, and the adoption of traditional technology architectural practices. To what extent can traditional notions help to the development of recent buildings that meet ergonomic requirements? This paper will explore the design integration of architecture and structure and advanced technology and traditional components of buildings in current building practices in Bali. By doing fieldwork, conducting a literature study, conducting interviews and structural analysis using SAP 2000, this paper investigates the appropriate architectural design and structural system that address the ergonomics of the building, the indigenous knowledge of the people, and the advance of technologies.

\section{Ergonomics, Architectures and Building Structures}

A recent academic study emphasized the critical nature of workplace design, which has a considerable impact on the ergonomics of building designs [13]. In this context, ergonomics is defined as a discipline that bridges human and automated work, with the primary objective of optimizing working conditions while taking human capabilities and performance constraints into account in a building [14]. Ergonomic principles are very significant in a building to provide places for repetitive activities, tasks that demand frequent raising and lowering actions, and jobs that involve handling heavy objects [15], [16].

The primary goal of ergonomic building design is to align work processes with employees' physical and psychological well-being and create buildings that facilitate the ideal arrangement of workpieces and tools in manufacturing and logistics [17]. In comparison to implementing a technology-centered workplace design, constructing a building design as a space for human-centered activities has the advantage of providing people with more comfort while performing their tasks. Humans who do their actions in an ergonomic building benefit from the usability, maintenance, and safety given by the design of the building's area [18].

The application of ergonomics in buildings positively affects productivity, comfort, and protection for safety and health [14], [19], [20]. In this context, the positive effects of ergonomics are related to economic productivities, 
where proper ergonomics produce better economics [21] and reduce the risk of injury by creating correct handling movement in a building design [22].

The numerous studies that have been conducted demonstrate precise results on how building contributes to the development of an ergonomic building [23]. Numerous contributions concern guidelines for building elements, including the required space dimensions, distance requirements, and building capability requirements, all of which are closely related to critical aspects of building structures. However, there is still a dearth of ergonomic considerations in methods that use the processes that must occur within a building as a starting point for architectural design [23], [24]. Despite the positive results of ergonomics early involvement in the building design process [25], [26], this critical aspect contributing to the development of ergonomic design is still somewhat unusual in building design.

The ergonomic approach is founded on observing the relationship between humans, systems, and the environment from an anthropocentric perspective. Although human factors in architectural design are not new, the model of designing on a human scale is merely a slogan because architects have traditionally considered only a few aspects of the human factor, primarily the average body size or stereotypical behavior of occupants [27]. Thus far, no attention has been paid to differences or mental aspects of perception and cognition processes at the level of an individual's function, level of independence, or psycho-physical well-being [28].

Throughout architecture's history, various buildings have been embellished with structures that demonstrate the function of the human body's proportions as a design reference. It is predicated on the belief that a beautiful form allows users to live a better life [27]. In this case, a complex three-dimensional system must consider the concept of anthropomorphic space to ensure that the design of a building is consistent with its primary living function and results in an optimal strategy.

This anthropocentric model has already been used in many traditional communities. However, this model has just gradually gained attention for recent buildings since the 1960s owing to the bioclimatic approach and regionalism in architecture [29]. This approach interprets the human body as a complex system of physiological and psychological responses to the built environment. Environmental psychology is also advancing, which has a significant impact on the model of physical regulation [30]. This model strongly supports the use of physical environmental parameters, human physiological parameters, and perceived well-being in the process of setting technical standards for comfort in the built environment [31]. Additionally, since the early 1980s, various Universal Design concepts have emphasized human diversity in order to define how the built environment and products should be rendered in order to produce aesthetics and be entirely usable by all, regardless of age, ability, or status in life [28].

In general, the structural system of an architectural design is not only a vehicle for architectural form but also a critical factor in formulating a facility's operational spatial plan. The structural planning of the building significantly impacts the development of an ergonomic architectural design [2]. Architectural planning has a significant influence on the structural system chosen, as structural design optimizes system space and zoning, affects the layout of space and interior spans, and thus has a significant impact on the building's ergonomics.

\section{Materials and Methods}

This paper investigates the integrated relationship between ergonomics, architectural, and structural aspects of the traditional Balinese building and its transformation. According to traditional Balinese rules, a hundred Balinese pavilions in Balinese houses were measured and compared to the owners' body size (owners' anthropometric). The subject's anthropometrics (body size), more precisely, the size of the body parts concerning the dimensions of the house components, were measured. This anthropometric was determined using a Super 686 anthropometer with a 1 $\mathrm{mm}$ resolution. The structural components' dimensions were then determined and compared to the rules of Balinese architecture known as asta kosala kosali to ensure that the buildings were constructed according to the anthropometry system.

After establishing the anthropometry of the structures for performance-based planning, a structural investigation was conducted, followed by a maximum horizontal deviation analysis. The ratio of the maximum horizontal deviation of the top to the height of the building is used to define this structural performance. The traditional structure was compared to the contemporary building structure. Additionally, response spectrum analysis was employed to conduct an additional investigation on the structural analysis of conventional tempered buildings. The SAP 2000 program was used to perform a dynamic analysis of the response spectrum in accordance with SNI 1726:2019. The response spectrum method is a technique for analyzing building structures that use an earthquake spectrum. The earthquake spectrum is a curve that represents the relationship between the period of the building structure and the acceleration value of the building itself when subjected to earthquake loads.

The traditional Balinese pavilion models were then analyzed using SAP 2000. During this structural evaluation, several aspects were examined, including static and live loads, which were the primary components used to study the building's structure. Due to the building's location within the ring of fire, earthquake loads had a significant role in determining the structure's stability. After that, the structural analyses of traditional pavilions were compared to those of pavilions with a concrete frame construction 
supported by bricks. The building's performance was determined by calculating the average maximum horizontal deviation of the building's top.

\section{Ergonomic Aspects in the Traditional Balinese Building}

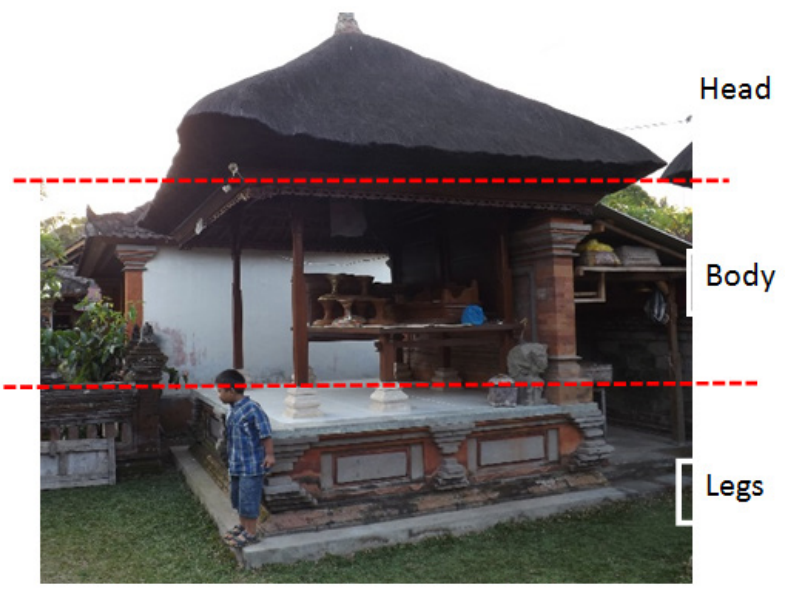

Figure 1. The Tri Angga Principle on the Form of Structures.

Traditional Balinese buildings are composed of several concepts that are implemented in a single structure. The first concept concerns the pavilions' shape and division. In this scenario, the space and building patterns are divided into three sections called tri loka, inspired by the tri hita karana philosophy. The top world (swah loka) is for God, the intermediate world (bwah loka) is for humans, and the lower world (bhur loka) is for demons [12], [32]-[34]. The notion then results in the tri angga, a physical split of the human body in which the world is divided into three traditional values, namely utama, madia, and nista, or a head, a body, and legs. Utama, or the head, refers to the highest, loftiest, or most sacred value; madia, or the body, refers to the center or neutral; and nista, or the legs, refers to the lowest, most profane value [35]-[38]. This idea was then applied to the buildings' structure (Figure 1).

The ergonomic concept that underpins the Balinese building approach is based on the anatomy of the property owner's body (anthropometry). Following its philosophical, ethical, and ritual foundations, this concept is incorporated into the construction of Balinese buildings [10]. Based on the ergonomic concept, each space in the Balinese buildings is measured using a different section of the owners' body (Figure 2). Each space in the Balinese buildings is measured using a different section of the owners' body (Figure 2). The buildings' width and length are measured in depa alit or depa agung (A). This module is defined as the distance between the middle fingers tips and the arms extended to their maximum length. Additionally, the pavilions and details of the building are measured using a variety of hand and finger compositions, including guli, cengkang, lengkat, and musti (C). Finally, the distance between pavilions is calculated using the length of a foot called tapak and the wide of a foot called tapak ngandang (B) [36], [37], [39], [40]. The units of measurement are derived from the asta kosala -kosali, a document containing ancient Balinese architectural rules and presenting that the ergonomic concept has been applied for the traditional Balinese building.

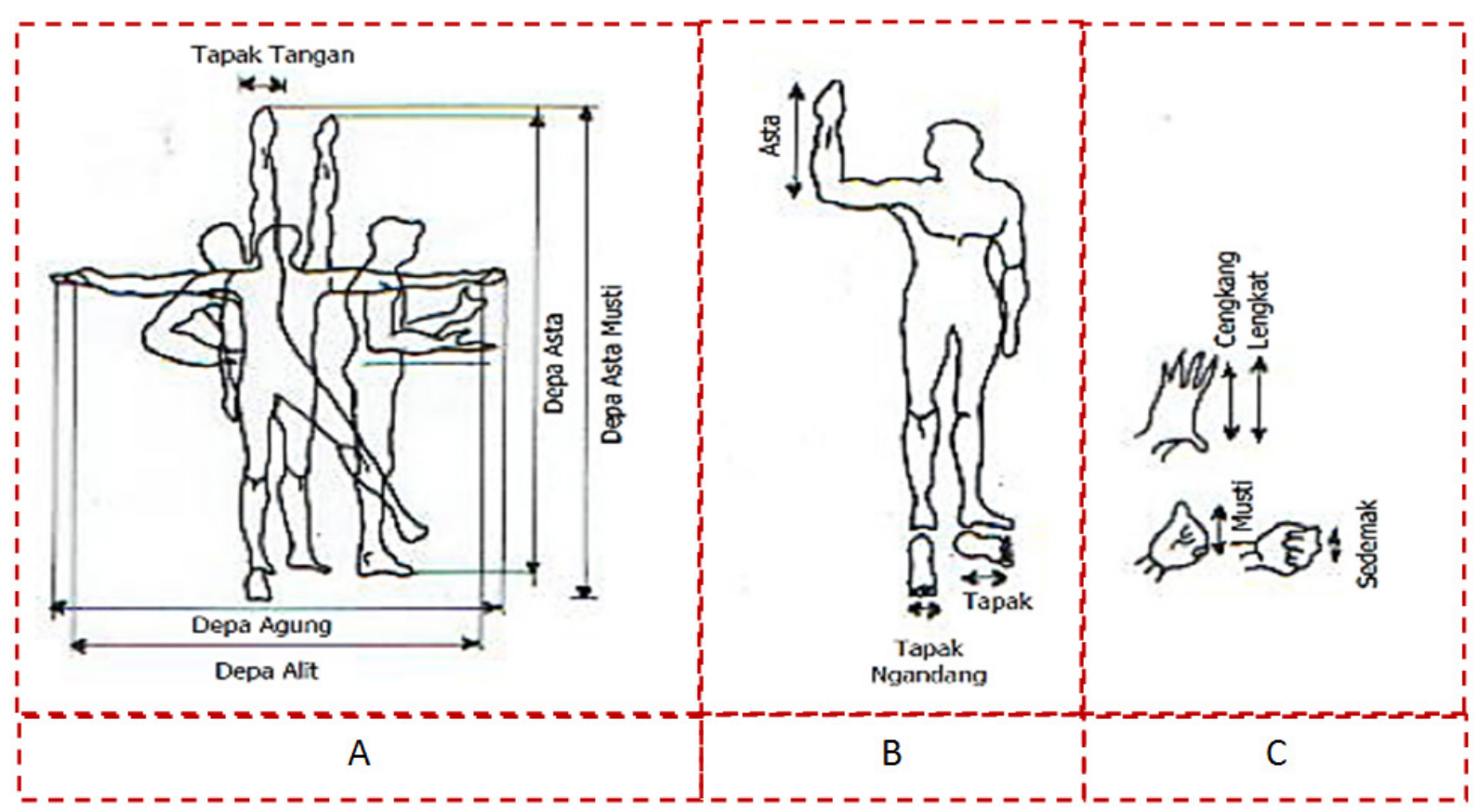

Source: Adhika 1994.

Figure 2. The Size of the Human Body as the Basis of Measurements for the Built Environment. 
The fundamental philosophy of a Balinese building is that all structural components are constantly visible, with no hidden features. This philosophy is referred to as the structure's honesty [41]. Roof, column, and structure frame elements and other components should demonstrate and convey their function and construction materials. They serve not only as structural components but also as adornments. The beauty was not achieved via ornamentation but through the arrangement of elements in accordance with their duties and roles in supporting the building (Figure 3).

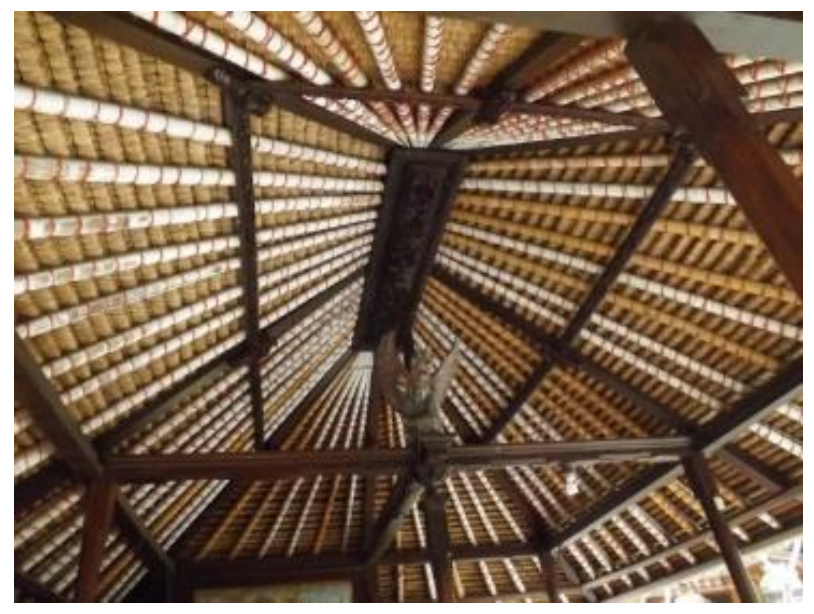

Figure 3. Honesty of a Roof Structure.

This traditional structural system supports the safety aspect of the building that is a part of the ergonomic aspect in the Balinese building. The Balinese building planning details various aspects of the building's arrangement, beginning with the architectural plan, structure, pillars (columns), floor, walls, roof, and ending with the interior (internal layout). Building columns, as structural members, aim for a unified and rigid connection with a connecting beam from one column to another as an element of the building's upper part that is supported by the foundation. Building materials are adapted to technological advancements in construction through proper processing and completion, and the benefits of asta kosala kosali determine the size of each structure components [35], [42][44].

As a part of the ergonomic features of the building, particularly in terms of safety, a highly efficient frame system is used to distribute vertical loads by columns called saka (5) and horizontal loads via beams called lambang (3). On the roof, the building structure is composed of rafters called usuk (2) that have been measured and calculated under traditional methods to ensure that they are strong enough to support the roof's weight. A ridge beam called petaka (1) at the top of the structure, which acts as a binder of rafters (usuk), plays a significant function in supporting the weight. These traditional structural components provide stability of the building in which the primary function of structures in buildings is to transfer all the loads acting on objects and provide sufficient rigidity and reliability [2]. According to traditional ergonomic principles, these structural functions are exhibited in the traditional Balinese structure erected from top to bottom. The load from the roof is transmitted to the beams called lambang and then to the column called saka supported by canggah wang (4) (Figure 4).

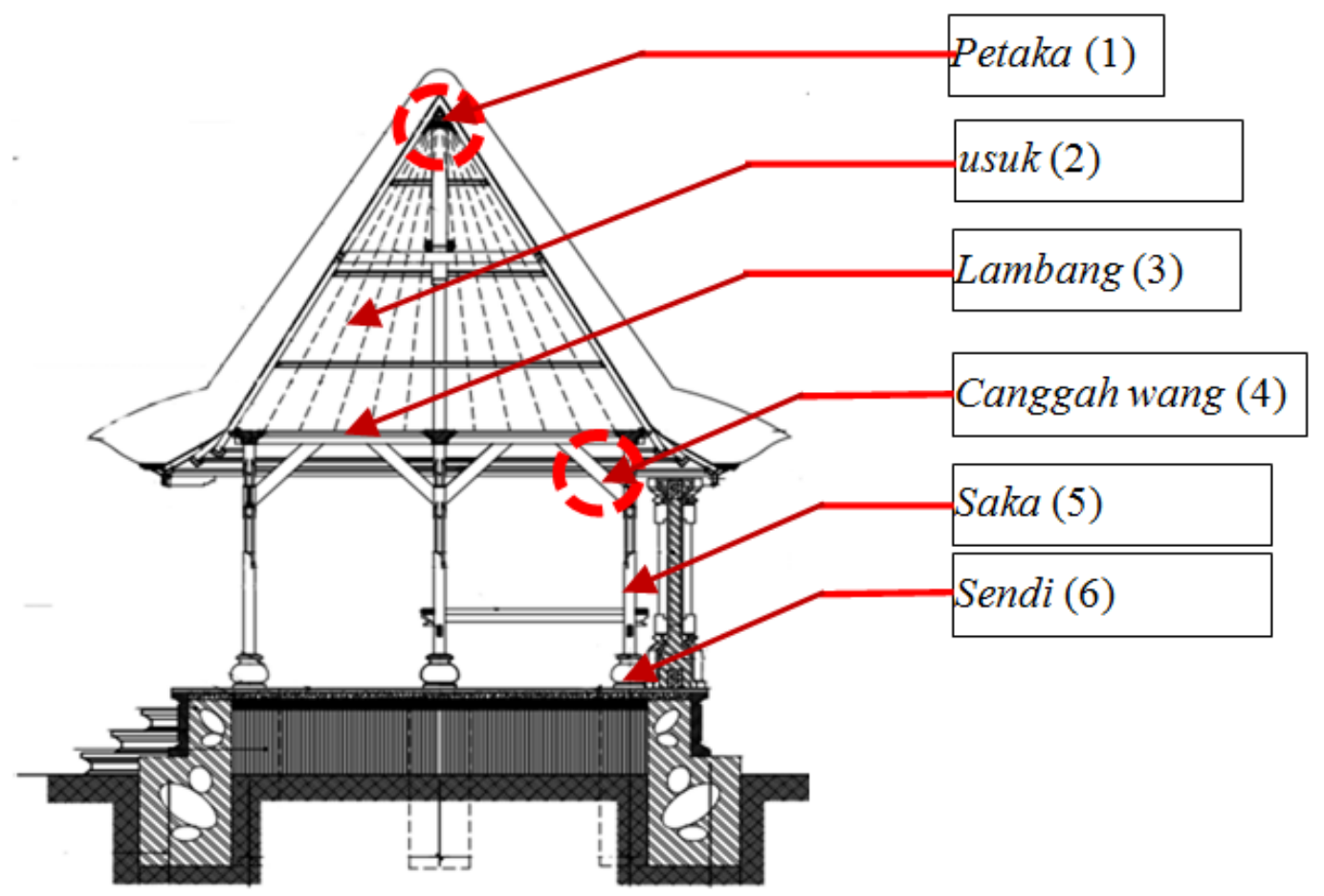

Figure 4. The Balinese Structural Components. 
The rigidity and reliability of the Balinese building's structure have presented the safety of the building in which the safety factors are a part of ergonomic components. From the results of the 3-dimensional analysis using the SAP 2000 software, the greatest horizontal variation of the top of the building and the height of the building has a stress ratio of 0.778 . This stress ratio shows that traditional Balinese building structures are robust enough to withstand earthquakes, indicating that traditional Balinese structures made of wood and light materials are both horizontally and vertically safe and can endure earthquakes. Balinese building structures, which on average use wood and bamboo, are relatively light and have a collapse rate of only $5-8 \%$ due to earthquake shocks [45].

The structure's ability to face the earthquake shock is the function of the building to ensure the safety of the occupants. This safety consideration is included in the ergonomic building requirement, which states that ergonomics benefits productivity, comfort, and the protection of people's safety and health [14], [19], [20]. In this term, the safety of the building is one of the essential elements to fulfill the requirement of ergonomic buildings, including using the owner's body (anthropometry) as a standard to measure a building.

Anthropometry in an ergonomic building is vital for product and spatial design development. The use of anthropometric is the way to design products for optimal comfort, safety, and functionality. It is essential to modify the anthropometrics of the user to accommodate every functional design to increase the user's ability to use it and reduce bad outcomes. To create the traditional Balinese building structure, the Balinese use the part of their body as the basis of the measurement standard. Based on the Balinese building philosophy, the idea behind the Balinese measurement method for construction is rooted in the owner's body (anthropometry). In this system, the distance from the column to the others is determined from the multiples of rai (Figure 5). This measurement system is also for the height of the column and other parts of the building's structure. At the last multiples, an excess called pengurip is equal to the owner's middle finger width [35], [40].

Column dimensions are determined by applying the appropriate approach rules in the traditional Balinese buildings. According to Balinese customary law (asta kosala kosali), the dimension of saka is measured based on a traditional module called rai. This size module is determined by the size of the owner's hand clasped with the thumb pointing upwards called amusti that is around 9-12 $\mathrm{cm}$ [10], [35], [37], [39], [40]. This module is then used to determine the column's height, in which the column height of a traditional Balinese building is $22 \mathrm{x} \mathrm{rai}$. The number 22 (twenty-two) is derived as a hereditary value for determining the height of a column capable of withstanding the compressive strength of wood for traditional building columns, and addressing the occupant activities' comfort (Figure 5). Using the part of the owner's body (anthropometry), the Balinese building guarantees its residents can do their activities in the building safely and comfortably.

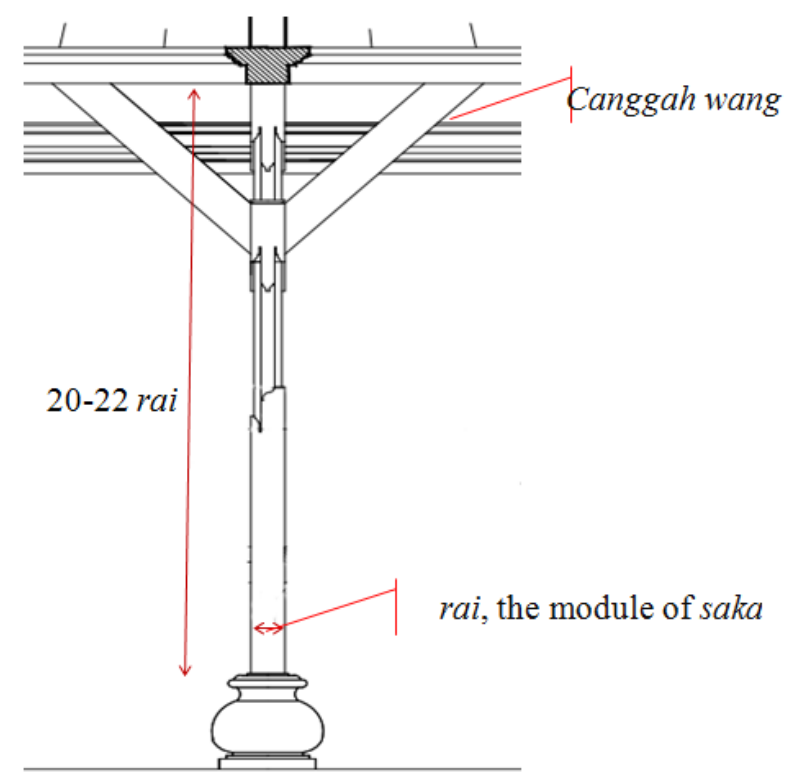

Figure 5. The Measurement of Column (Saka).

Saka is supported by canggah wang (Figure 5). It is an essential component in the structural system of Balinese buildings that can support the structure from a load of an earthquake. This can be seen from the structure analysis using SPA 2000. Based on the dynamic analysis, the deviation of the structural system without the canggah wang, when struck by an earthquake, is $17.86 \mathrm{~cm}$ (on the $\mathrm{x}$-axis direction) and $16.35 \mathrm{~cm}$ (on the $\mathrm{y}$-axis direction) (Figure 6). On the other hand, the deviation (wobble) of the structural system supported by the canggah wang is 7.99 $\mathrm{cm}$ in the $\mathrm{x}$-axis and towards $6.36 \mathrm{~cm}$ on the y-axis. Therefore, the canggah wang can improve the behavior of the structural system, in which the deviation becomes smaller when hit by an earthquake, to reduce the possibility of failure. This can increase security for residents of the building. 


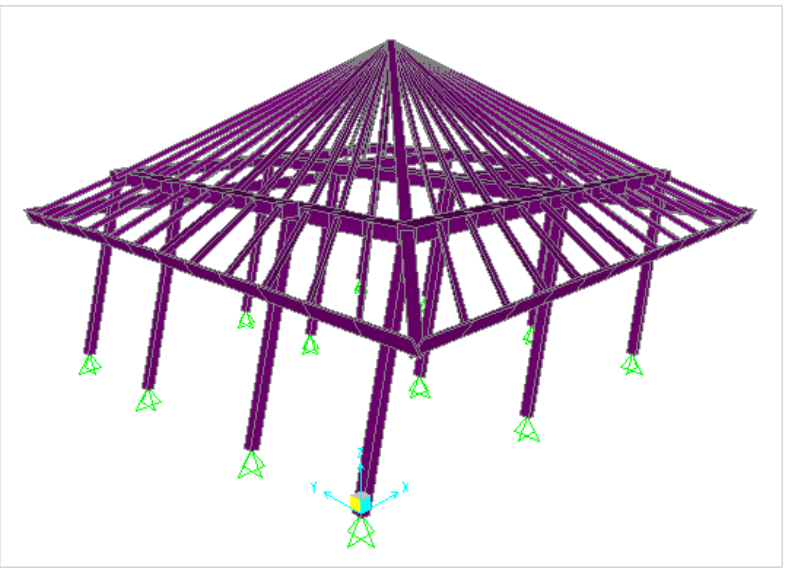

a. The structure without canggah wang

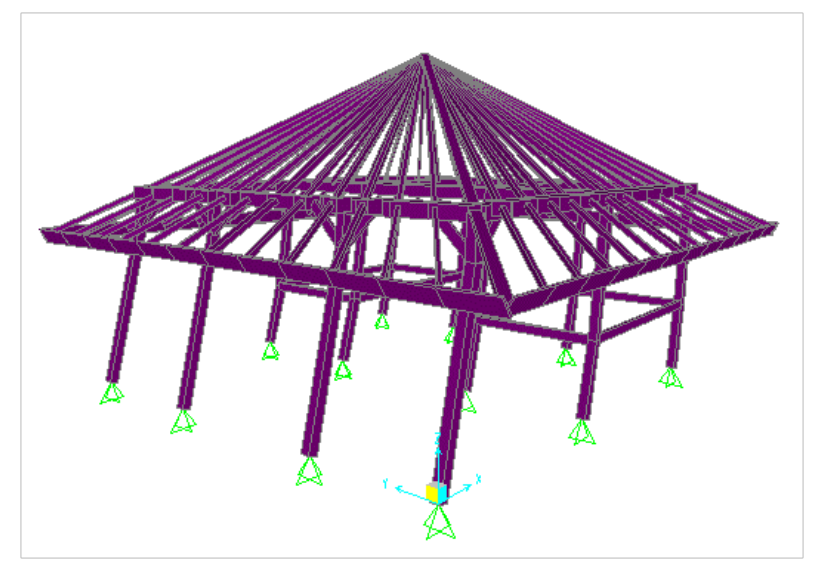

b. The structure with canggah wang

Figure 6. Comparation Analysis Earthquake Loads in Structure with and without Canggah Wang.

\section{The Application of Ergonomic Aspects in the Contemporary Balinese Building}

The ergonomic system in buildings has made the Balinese aware of their traditional knowledge. In this condition, the idea has recently emerged to apply indigenous wisdom to human and environmental problems, hoping that it will be more readily accepted by the indigenous community, such as the tri hita karana philosophy.

However, Balinese culture has changed to fit its inhabitants' changing needs and lifestyles. The increased living level has influenced numerous facets of Balinese life, including construction methods. While old construction procedures relied on anthropometric systems, contemporary buildings employ meter-based measurement standards, with the building often adhering to international norms. The anthropometric system has been abandoned and just used for ritual buildings such as temples, household temples, or pavilions for ceremonial activities. From 121 traditional houses that have been transformed in Ubud, the cultural tourism village in Bali, 90\% of non-ritual buildings have not used the anthropometric system. For the new generation of Bali, the new system is easier to implement in which the people helped architects or designers use international standards for the size of the building components (Figure 7). The use of such a measurement system has caused discomfort for the Balinese since the body's size is different. Comfort for someone who is not quarantined will also comfort others. Therefore, using an anthropometric system based on the occupant's body's size as a reference for a measurement system is essential, especially for housing or private workplaces.

The new structural technology has been used in many parts of the buildings, such as the use of concrete and walls as a part of structural systems. Traditional Balinese buildings used wood-frame structures with walls that served only as partitions; the new structure model is a concrete-frame structure supported by walls that serve as structural components. Interactions with foreign cultures, and the unfolding transformation of social and cultural relations among the local people, have a significant impact on accepting a new tradition [46], including structural system practices.

This transformation is related to the four dimensions of architecture and structure that have mutual relations. The four dimensions are three spatial dimensions and time. This relation is the problem of the transience of building. The buildings are aging in several aspects: technical, functional and aesthetic, in which the average building life is around one hundred years [2]. After this time, every object except monumental structures - has lost its utility in terms of space requirements, technology, strength and structural requirements, and architectural style. In these aspects, modernization has altered people's lifestyles, including many aspects of socio-cultural life in Bali. Being modern for the Balinese is associated with meeting the new standard of living [47], in which being modern means meeting the needs of the people in the modern era to present the owner personal self-expression. 


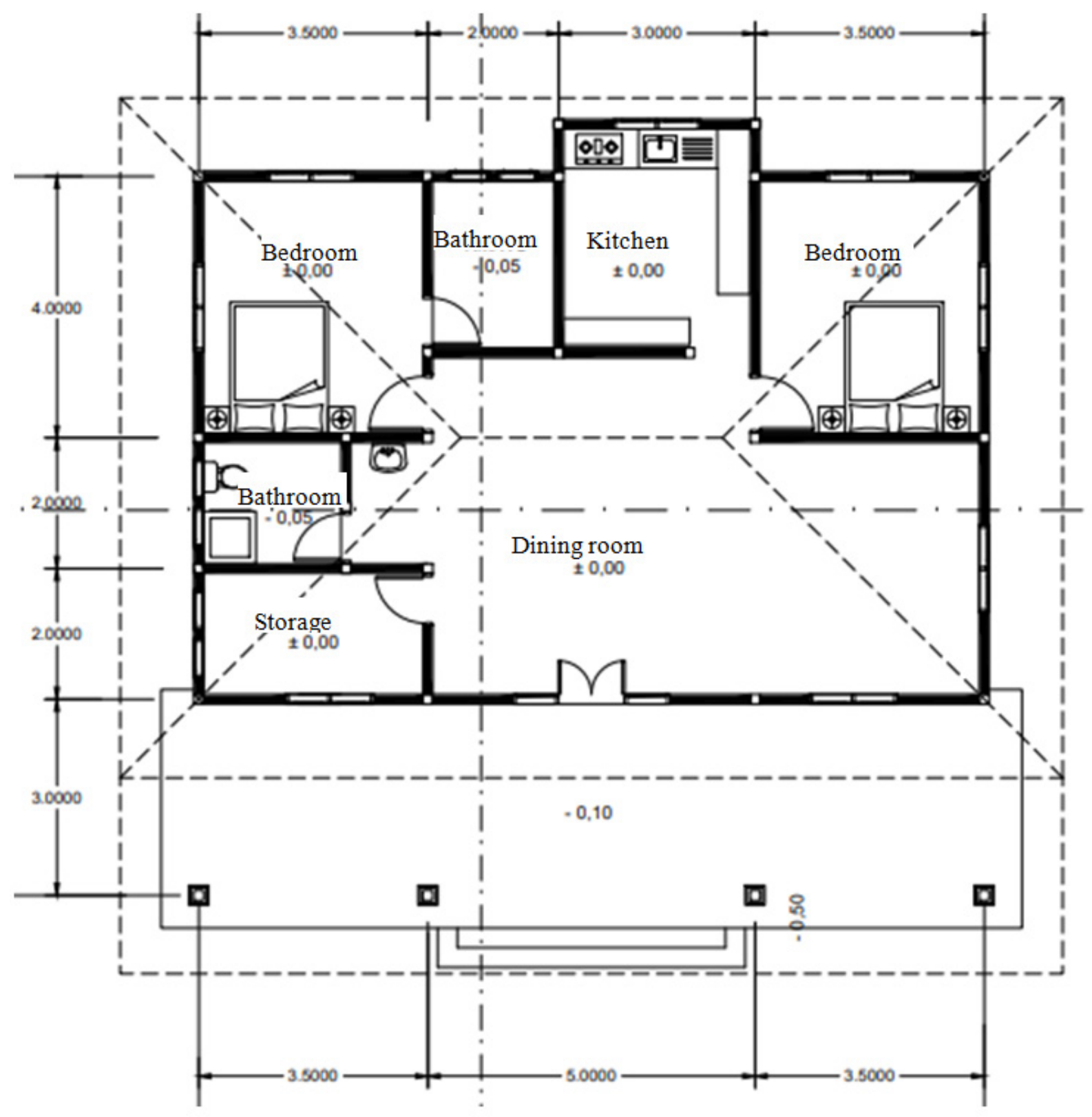

Figure 7. The Plan of a Building Used Meter Basis Measurement.

To communicate personal self-expression [48], the new standard of life has encouraged people to adapt their buildings to the new needs and demands. There are two options for an old building in adaptation and transformation: modernization or demolition. This quandary manifests itself in a categorical form at the end of the life of the building, but the entire period is a formation process spread over many years (investment preparation, design, and realization) due to the constant need to adapt. However, this transformation is related to the possibility of continuous modernization due to changes in human needs, lifestyles [11] and working behaviour [49], so for some things whose construction period has expired, a decision for radical changes must be made [50]. In this context, the solution chosen must become adaptable as possible to allow the maximum transformation of the building's structure and architecture.

The change of people's demands has also changed the typology of the building. Traditionally, most buildings were wood-frame structure systems in which the buildings were primarily open spaces without walls or walls on one or two sides, and have already changed to enclosed room buildings to accommodate people's desires to perform individual activities privately in enclosed rooms. The need for enclosed rooms has produced a new building typology. This new typology is broader than a traditional pavilion. This construction has led to an increase in space demands that require more prominent buildings. Unlike traditional pavilions, such buildings produce potential problems related to the safety of the building structure. An essential 
aspect of selecting a structural system is accommodating the functional schemes required to accommodate occupant activities. In designing these structural systems, the spatial interweaving of architectural functions with structural performance needs varying parameters of the structural system for span, height, load, dynamic impact, opening and size [2].

The ratio of the top's maximum horizontal deviation and the building's height is defined as the relationship between these two quantities. Traditional buildings, primarily constructed of timber frame structures, are currently being phased out in favor of brick and reinforced concrete structures. The ability of a structure to withstand earthquake loads can be determined by its most significant horizontal deviation. Using SAP 2000, the results of the 3-dimensional analysis of the four traditional buildings and four new building models obtained that the average maximum horizontal deviation of the top of the building is $2.965 \mathrm{~cm}$ with a building height of $375 \mathrm{~cm}$ for traditional buildings (Figure 8 -a) or with a ratio of 0.008 . Meanwhile, buildings with a concrete structure system supported by brick walls (Figure 8-b) which are usually called modern traditional buildings [51], produce an average maximum horizontal deviation of the top of the building of $0.193 \mathrm{~cm}$ with a building height of $375 \mathrm{~cm}$ or a ratio of 0.0005 (Table 1). The average performance of contemporary buildings increased by $14.56 \%$.

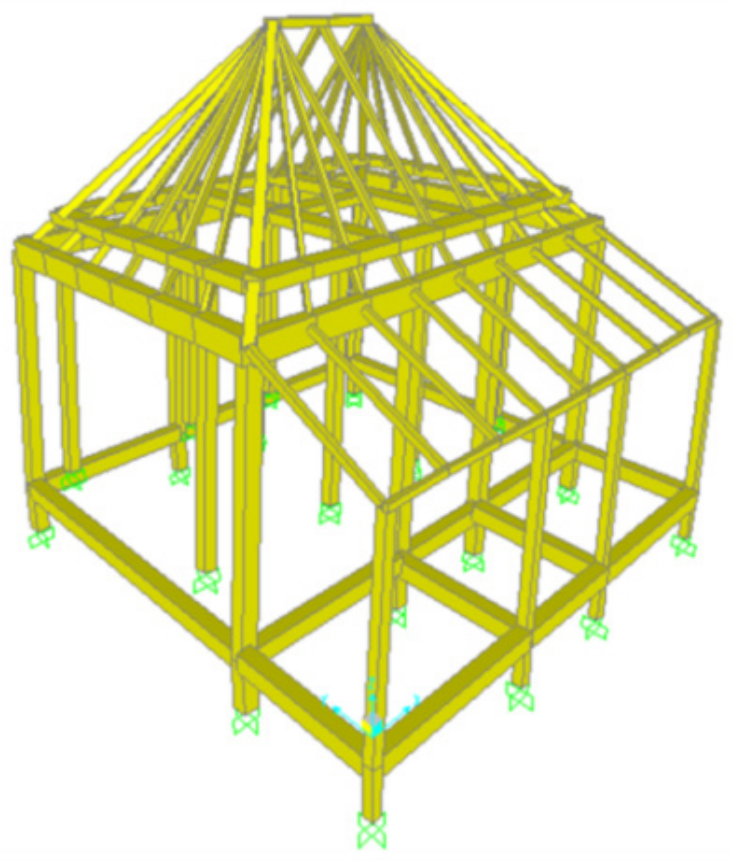

a. The traditional building structure.

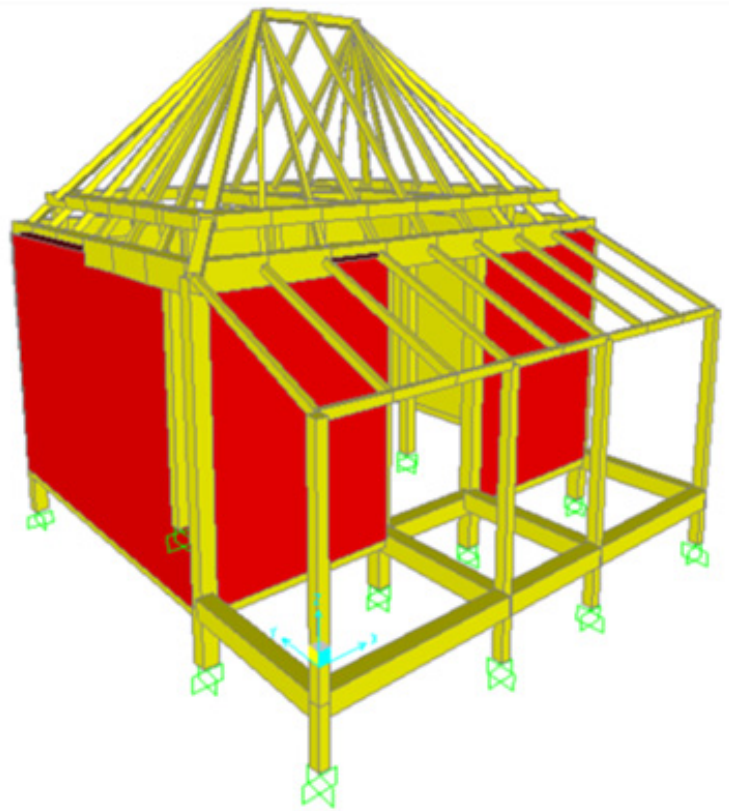

b. The contemporary building structure

Figure 8. The Traditional and Contemporary Building Structure.

Table 1. The Structural Analysis Comparison

\begin{tabular}{ccc}
\hline No & $\begin{array}{c}\text { Traditional } \\
\text { Building }\end{array}$ & $\begin{array}{c}\text { Contemporary } \\
\text { Building }\end{array}$ \\
\hline $\begin{array}{c}\text { Maximum horizontal } \\
\text { deviation (average) }\end{array}$ & $2.965 \mathrm{~cm}$ & $0.193 \mathrm{~cm}$ \\
\hline Stress Ratio & 0.008 & 0.0005 \\
\hline
\end{tabular}

According to this rise, the new structural system performs better when subjected to an earthquake, making it safer for tenants to dwell in their buildings. Therefore, the building addresses the ergonomic requirements, especially the safety aspect. One of the most critical problems is integrating architectural and structural aspects to determine the optimal structural system for selecting the functional layout used in the building. In this case, the introduced classification enables a direct relationship between structure and function at the level of an idealized schema. The integration of the construction system with the functional layout and architectural form is required before starting and designing a building.

In order to perform this critical function of ergonomics in a building, architecture and structural systems must be fully linked to ensure a more functional layout and optimum space, considerably improving the ergonomics of space solutions. The structural design of contemporary buildings in Bali, Indonesia, should consider that Indonesia is prone to earthquakes due to its geographic location. This region is a collision zone for tectonic plates from the Pacific, Indo-Austrian, and Eurasian plates. A seismic-resistant structure must be constructed and studied to comply with existing rules, utilizing dynamic analysis of response spectra to mitigate the intensity of the earthquake's impacts. 
The reaction spectrum in Bali is depicted in Figure 9, based on the online Applications Indonesia Design Response Spectrum 2019 and the Indonesian National Standard [52]. This picture illustrates the relationship between the structure's vibration period and its maximal response to a particular earthquake. Indonesian building rules have been modified to incorporate the Maximum Considered Earthquake Response (MCER) for a uniform ground condition and the Design Basis Earthquake (DBE). The most recent edition of the Indonesian building codes is (SNI) 1726-2019 [52]. The DBE level was used to conduct the subsequent inquiry into the SAP 2000 program.

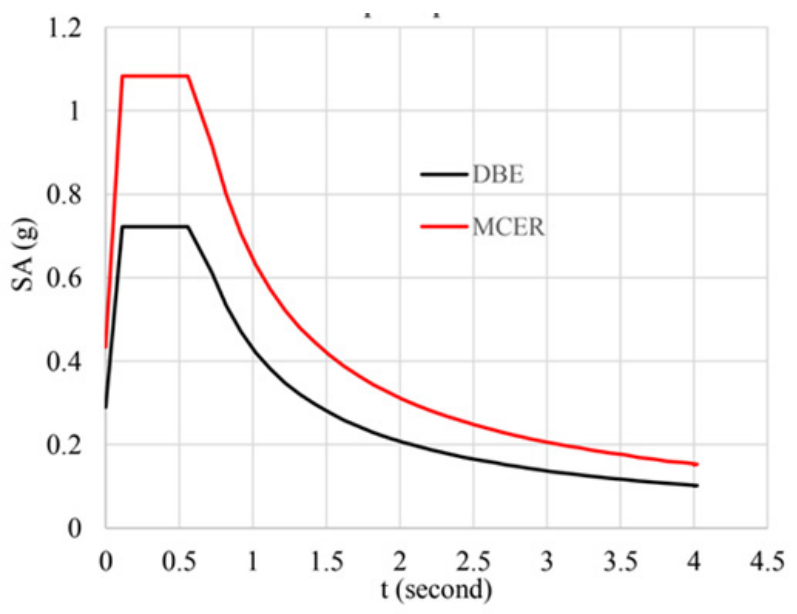

Figure 9. Response Spectrum Curve for Earthquake Loading.

Following that, based on Indonesian National Standard (SNI) 1726-2019 [52], seismic loading data were used to analyze the fundamental sliding style. This standard was used to compare the structure's dynamic and static responses. The dynamic reaction in the $\mathrm{x}$ and $\mathrm{y}$ directions (3064,73 and 3075,14 , respectively) was more significant than the static response in those directions $(2212,23$ and 2211,24 , respectively) (Table 2). This information suggests that the structure is stable due to the earthquake.

Table 2. Basic Sliding Styles

\begin{tabular}{ccc}
\hline $\begin{array}{c}\text { Earthquake } \\
\text { Force Direction }\end{array}$ & $\begin{array}{c}\text { Dynamic } \\
\text { Earthquake }\end{array}$ & Static Earthquake \\
\hline X direction & 3064,73 & 2212,23 \\
\hline Y direction & 3075.14 & 2211,24 \\
\hline
\end{tabular}

However, the need for an anthropometry system to produce ergonomic buildings has already made Balinese aware of their local wisdom to use their traditional practices to measure the size of the buildings. This measurement system can create ergonomic buildings to accommodate their activities and personalize their demands and lifestyle. Along with the times, ergonomic building requirements have given rise to applying local wisdom in dealing with human and environmental problems, hoping that the local community will more readily accept it. Nevertheless, some of the values in local wisdom have been forgotten and eroded by new technologies that may be considered more sophisticated. Some traditional building practices need to adopt new technologies to provide a better sense of security and comfort about the ever-changing building safety requirements. In this case, the structural system used needs to be adjusted to provide a better level of building security without eliminating local wisdom that is owned by combining the new system with the old system.

\section{Conclusions}

The ergonomic rules must be dependable, meeting the standards for safety, health, comfort, and convenience stipulated in the building regulations, including the ergonomic rule of safety in a traditional Balinese building. Traditionally, the Balinese used their body size to estimate building size. Ergonomics is the science of matching tools, workstations, and jobs to users by eliminating symptoms caused by improper tool use or a suboptimal work environment. Based on the owner's body, the Balinese construct buildings using anthropometry principles. Traditionally, each space in a Balinese building is measured by a distinct body part. Therefore, buildings measured using the owner's body are more harmonious and comfortable for their occupants.

Many aspects of Balinese life, including architectural practices, have been influenced by modernity. Architects now use meter-based measurements, which are an international standard, rather than anthropometric measurements. Because people's bodies vary in size, using a measurement system like this has made it difficult for designers to provide different size standards for each design. It is necessary to use an anthropometric system based on the inhabitants' body size as a reference for measuring, especially in houses or private workspaces. The novel structural technique has been used in various structural elements, including concrete and walls. Traditional Balinese buildings were built with wood-frame structures and partition walls, whereas the new structure model is built with concrete-frame structures and structural walls. SAP 2000 was used to conduct a three-dimensional examination of four classic buildings and four new building models.

As a result of the requirement for an anthropometry system to develop ergonomic buildings, the Balinese have already become aware of their local wisdom, which includes using their traditional methods to measure the size of the structures. Some old building practices will need to be updated with new technologies to comply with new building safety regulations. This adoption will create a better sense of security and comfort regarding the constantly changing building safety regulations, which will benefit everyone. 


\section{REFERENCES}

[1] A. Sabarudin, "Bangunan Rumah Sederhana Tahan Gempa Pada Konstruksi Bangunan Rumah Tembok 1/2 Bata," Bandung, 2012.

[2] J. Jablonska, E. Trocka-Leszczynska, and R. Tarczewski, "Structure vs Ergonomic in Contemporery Hotel Design," in International Conference on Universal Access in HUman-Computer Interaction, 2016, pp. 282-292, doi: 10.1007/978-3-319-40250-5_28.

[3] I. N. Sutarja, M. D. W. Ardana, and I. D. G. A. D. Putra, "The post-disaster house: Simple instant house using lightweight steel structure, bracing, and local wood wall," Int. J. Eng. Trans. B Appl., vol. 34, no. 2, pp. 348-354, 2021, doi: 10.5829/IJE.2021.34.02B.06.

[4] Y. Hutabarat, Dasar-dasar Pengetahuan Ergonomi, vol. 148. Malang: Media Nusa Creative, 2017.

[5] F. P. Obinna, A. A. Sunday, and O. Babatunde, "Ergonomic assessment and health implications of classroom furniture designs in secondary schools: a case study," Theor. Issues Ergon. Sci., vol. 22, no. 1, pp. 1-14, 2021, doi: 10.1080/1463922X.2020.1753259.

[6] A. Mizsei and G. Horv, "Safe Haven — Bath House and Library by the Burmese Border," Heritage, vol. 4, pp. 2105-2123, 2021.

[7] R. Alfatiyah and W. Marthin, "Redesign Kursi dan Meja Perkuliahan Dengan Metode Quality Function Deployment (QFD) Secara Ergonomis Di Program Studi Teknik Industri, Universitas Pamulang," Pros. Semin. Ilm. Nas., pp. 76-88, 2017.

[8] I. Aribowo and W. Sutopo, "Seminar dan Konferensi Nasional IDEC Studi Perkembangan Intervensi dengan Pendekatan Ergonomi dalam Mengurangi Keluhan Muskuloskeletal Disorder pada Operator Mesin Jahit," Idec.Ft.Uns.Ac.Id, no. 1996, pp. 2-3, 2019, [Online]. Available:

https://idec.ft.uns.ac.id/wp-content/uploads/2019/05/ID010 .pdf.

[9] E. Attaianese and G. Duca, "Human factors and ergonomic principles in building design for life and work activities: An applied methodology," Theor. Issues Ergon. Sci., vol. 13, no. 2, pp. 187-202, 2012, doi: 10.1080/1463922X.2010.50 4286.

[10] I. W. Parwata, A. A. G. Oka Wisnumurti, and N. W. Meidayanti Mustika, "Anthropometry and Ergonomic of Bale Sakenem (Case Study: Central Singapadu Village, Gianyar)," J. Sustain. Dev., vol. 10, no. 6, p. 222, 2017, doi: 10.5539/jsd.v10n6p222.

[11] I. D. G. A. D. Putra, "'Stay at home' for addressing COVID-19 protocol: learning from the traditional Balinese house," Archnet-IJAR, vol. 15, no. 1, pp. 64-78, 2020, doi: 10.1108/ARCH-09-2020-0187.

[12] I. D. G. A. D. Putra, M. Lozanovska, and R. Fuller, "From spiritualistic toward more pragmatic pattern: Re-ordering Balinese houses and viability of the household traditions in tourism economy," J. Archit. Urban., vol. 43, no. 1, 2019, doi: 10.3846/jau.2019.3692.

[13] T. Gruchmann, A. Mies, T. Neukirchen, and S. Gold, "Tensions in sustainable warehousing: including the blue-collar perspective on automation and ergonomic workplace design," J. Bus. Econ., vol. 91, no. 2, pp. 151178, 2021, doi: 10.1007/s11573-020-00991-1.

[14] P. Vink, E. A. P. Koningsveld, and J. F. Molenbroek, "Positive outcomes of participatory ergonomics in terms of greater comfort and higher productivity," Appl. Ergon., vol. 37, no. 4 SPEC. ISS., pp. 537-546, 2006, doi: 10.1016/j.apergo.2006.04.012.

[15] E. H. Grosse, C. H. Glock, M. Y. Jaber, and W. P. Neumann, "Incorporating human factors in order picking planning models: framework and research opportunities," Int. J. Prod. Res. Taylor Fr. Journals, vol. 53, no. 3, pp. 695-717, 2015, doi: 10.1080/00207543.2014.919424.

[16] A. Otto, N. Boysen, A. Scholl, and R. Walter, "Ergonomic workplace design in the fast pick area.," OR Spectr., vol. 39, pp. 945-975, 2017.

[17] R. Conti, J. Angelis, C. Cooper, B. Faragher, and C. Gill, "The effects of lean production on worker job stress. 10131038," Int. J. Oper. Prod. Manag., vol. 26, no. 9, pp. 1013 1038, 2006.

[18] H. W. Hendrick, "Determining the cost-benefits of ergonomics projects and factors that lead to their success.," Appl. Ergon., vol. 34, pp. 419-427, 2003.

[19] J. Rosecrance, D. Dpuphrate, and S. Cross, "Integration of participatory ergonomics and lean manufacturing: a model and case study," Hum. Factors Organ. Des. Manag., vol. 6, pp. 437-442, 2005.

[20] A. Hedge and W. Sakr, "Workplace effects on office productivity: A macroergonomic framework," in Human factors in Organizational Design and Management - VIII, P. Carayon, M. Robertson, B. Kleiner, and P. L. T. Hoonakker, Eds. Santa Monica: IEA Press, 2005, pp. 7580

[21] H. W. Hendrick, Good ergonomics is good economics. Santa Monica: HFES press, 2001.

[22] S. A. Lavender, C. M. Sommerich, M. R. Johnson, and Z. Radin, "Developing ergonomic interventions to reduce musculoskeletal disorders in grocery distribution centers," Proc. Hum. Factors Ergon. Soc., vol. 2, pp. 1229-1233, 2010, doi: 10.1518/107118110X12829369834762.

[23] S. L. M. Remijn, "Integrating ergonomics into the architectural design processes: Tools for user participation in hospital design," ErgoS Ergon. Eng., pp. 10-14, 2006, [Online]. Available:http://citeseerx.ist.psu.edu/viewdoc/do wnload?doi=10.1.1.463.7799\&rep=rep1\&type $=$ pdf.

[24] J. E. Harrigan, Human factors research: methods and applications for architects and interior designers. Amsterdam: Elsevie, 1987.

[25] T. Engström, L. G. Bergqvist, and J. Gasslander, "Linkage of user demands to the building facility," 2001.

[26] J. Villeneuve, "The contribution of ergonomics to the design of hospital architecture.," in In Proceedings of the Human Factors and Ergonomics Society Annual Meeting (Vol. 44, No. 26), 2000, pp. 189-196.

[27] E. Attainase, "Ergonomic Design of Built Environment," VI Encontro Nac. Ergon. do WMbiente Construido VII Eminario Bras. Acessibilidade Integr., vol. 2, no. 7, pp. 15, 2016, doi: 10.5151/despro-eneac2016-palamb1. 
[28] E. S. Greenhouse, "Human-centered design.," Retrieved from Livable New York http//www. aging. ny. gov/LivableNY/ResourceManual/DemographicAndSoci alTrends I, vol. I, no. 9, 2012.

[29] V. Olgyay, Design with Climate. Princeton: Princeton University Press, 1963.

[30] Proshansky, H. M., Environmental Psychology: men and his physical setting. Holt: Rinehart and Winston, 1970.

[31] K. Fabbri, "A Brief History of Thermal Comfort.," in Indoor Thermal Comfort Perception, K. Fabbri, Ed. Springer, 2015.

[32] A. Hobart, U. Ramseyer, and A. Leemann, The people of Bali. Massachusetts: Blackwell Publishers Ltd, 2001.

[33] F. Eiseman Jr, Sekala and niskala: essays on religious, ritual and art, vol. I. Singapore: Periplus Editions, 1989.

[34] I. D. G. A. D. Putra, I. B. G. Wirawibawa, and M. W. Satria, "Spatial orientation and the patterns of the traditional settlement in the eastern Bali: Investigating new tourism atractions," Geoj. Tour. Geosites, vol. 29, no. 2, 2020, doi: 10.30892/gtg.29218-493.

[35] I. N. Gelebet, Arsitektur Tradisional Bali (Balinese Traditional Architecture). Denpasar: Bappeda Bali, 1998.

[36] N. K. A. Dwijendra, "Meru as a hindu sacred building architecture with a high roof and resistant to earthquakes in Bali, Indonesia," Civil Engineering and Architecture, vol. 8, no. 3, pp. 350-358, 2020, doi: 10.13189/cea.2020.080319.

[37] H. Kagami, "Balinese traditional architecture in process, the Little World Museum of Man.” Inuyama, 1988.

[38] I. D. G. A. D. Putra, I. M. Adhika, and A. A. G. A. Yana, "Reviving Cultural Tourism in Kendran Bali Indonesia: Maintaining Traditional Architecture and Developing Community-based Tourism," Civil Engineering and Architecture, vol. 9, no. 2, pp. 328-338, 2021, doi: 10.13189/cea.2021.090206.

[39] I. M. Adhika, "Peran banjar dalam penataan komunitas, studi kasus Kota Denpasar," Institut Teknologi Bandung Indoensia, 1994.

[40] L. E. A. Howe, "An introduction to the cultural study of traditional Balinese architecture," Archipel, vol. 25, pp. 137-158, 1983.

[41] E. Budihardjo, “Architectural conservation in Bali," 1986.

[42] M. Covarrubias, Island of Bali. Singapore: Periplus Editions, 2015.

[43] R. Y. D. Tan, "The domestic architecture of South Bali," Bijdr. tot taal-, land-en volkenkunde/Journal Humanit. Soc. Sci. Southeast Asia, vol. 123, no. 4, pp. 442-475, 1967.

[44] I. B. G. Wirawibawa, I. D. G. A. D. Putra, and N. K. A. Dwijendra, "'Memada-mada': The power relation and architectural creativity of gianyar palace," Civil Engineering and Architecture, vol. 9, no. 3, pp. 949-957, 2021, doi: 10.13189/cea.2021.090336.

[45] I. W. Parwata, "Pengaruh Sistem Struktur Pada Bangunan Arsitektur Bali Terhadap Guncangan Gempa (Studi dengan menggunakan Soft Ware SAP 2000)," Denpasar, Bali, 2016. [Online]. Available: https://api.semanticscholar.org/Corpu sID:127269673.

[46] J. R. Gusfield, "Tradition and modernity: misplaced polarities in the study of social change.," Am. J. Sociol., vol. 72, no. 4, pp. 351-362, 1967.

[47] A. Vickers, "Modernity and being modern: an introduction," in Being modern in Bali: image and change, A. Vickers, Ed. New Haven: Monograph 43/ Yale University Southeast Asia Studies., 1996, pp. 1-37.

[48] C. C. Marcus, House as a mirror of self: exploring the deeper meaning of home. Bewick: Nicolas-Hays, 2006.

[49] W.O. Sifatu, H. Sjahruddin, Y. Fajriah, N.K.A. Dwijendra and A. Santoso, "Innovative work behaviors in pharmacies of Indonesia: role of employee voice, generational diversity management and employee engagement," Sys. Rev. Pharm, vol. 11, no. 2, pp. 725-734, 2020.

[50] G. Vickers, 21st Century Hotel. Londan: Laurence King Publishing, 2005.

[51] I. G. M. Putra, Perumahan. Denpasar: Jurusan Arsitektur Universitas Udayana Bali, 1984.

[52] BSN, Tata Cara Perencanaan Ketahanan Gempa untuk Struktur Bangunan Gedung dan Nongedung, SNI 1726 2019. Jakarta, 2019. 